\title{
A brief discussion of the politicization of the judiciary and the view of its application in Brazilian law
}

\author{
By Humberto Theodoro Junior, Dierle Nunes, Alexandre Bahia*, \\ Belo Horizonte
}

\section{A. Initial considerations - the problem of comparative studies}

By way of introduction, we need to point out that any approach to this subject would be reductionist because of the complexity of the issue of politicization of Justice or the legalization of politics (the economy and the institutional agenda) in other countries and especially in Brazil. It would be reductionist to approach the issue by way of a dialogue between advocates of judicial activism and those "supporters" of the concept of selfrestraint - minimalists. This is because both conceptions, both of which are extreme views, can lead to a gullibility in the virtues of the decisor solipsistic (Judiciary), in the first case, or reduce the role of the procedural and judicial spheres in pursuit of fundamental rights not offered to citizens in the second case. It would also be a limited approach if we treated the controversy from the perspective of the so called Public Interest Litigation, as has been done in numerous countries following the 1976 work of Professor Abram Chayes, Harvard Law School, which referred to the practice of lawyers in the United States seeking to precipitate social change through the bringing of claims involving the restructuring of key institutions of government, including public schools, mental hospitals, clinics and prisons, affecting thousands of people. ${ }^{1}$

Humberto Theodoro Junior, Full Professor at Universidade Federal de Minas Gerais School of Law. Retired Judge of the Supreme Court of the State of Minas Gerais. Member of: Academia Mineira de Letras Jurídicas, Office of Lawyers of Minas Gerais, Institute of Comparative Law Luso-Brazilian, Brazilian Institute of Procedural Law and Instituto Ibero Americano de Derecho Procesal e da International Association of Procedural Law. E-mail: htj@htj.adv.br.

Dierle Nunes, $\mathrm{PhD}$ in Procedural Law (PUCMinas / Università degli Studi di Roma "La Sapienza"). LL.M in Procedural Law (PUCMinas). Professor at the Universidade Federal de Minas Gerais (UFMG), Faculdade de Direiro do Sul de Minas (FDSM) and the Pontifical Catholic University of Minas Gerais (PUCMinas). Member of the Brazilian Institute of Procedural Law (IBDP), and the Institute of Lawyers of Minas Gerais (IAMG). Lawyer and partner in the Office of Camara, Rodrigues, Oliveira \& Nunes Associate Lawyers. E-mail; dierlenunes@gmail.com.

Alexandre Bahia, PhD in Constitutional Law (Federal University of Minas Gerais). LL.M in Procedural Law (Federal University of Minas Gerais). Professor in the Masters Program in Law at Faculdade de Direiro do Sul de Minas (FDSM). Member of the Brazilian Institute of Procedural Law (IBDP). E-mail: alexprocesso@gmail.com.

1 Adam Chayes, The Role of the Judge in Public Law Litigation, Harvard Law Review, 89 (1976), 1281. Helen Hershkoff, Public Interest Litigation: Selected Issues and Examples. $<$ www1.worldbank.org/publicsector/legal/PublicInterestLitigation>. Accessed in: 26 November 2004. 
This discussion is becoming important in countries like South Africa ${ }^{2}$, Ethiopia ${ }^{3}$ and India ${ }^{4}$, among others ${ }^{5}$, in discussing the role of a judicial and procedural framework for the achievement of fundamental rights for marginalized groups and social classes who do not have a voice in public arenas (e.g. parliaments) to defend their rights. The lawsuit as a contra-majority spacet o raise fundamental rights. However, there is a constant reference in the handouts implemented by the Court presided over by Earl Warren in the U.S. Supreme Court, with indications of the precedents set in 1954 and 1955, Brown vs. Board of Education of Topeka, in which the aforementioned Court declared the racial segregation of public school students unconstitutional. As Hershkoff stated, the Brown precedent "gave inspiration to a generation of lawyers who saw the law as a source of liberation and transformation for marginalized groups," or saw a remedy in the counter-majoritarian mechanism by which groups marginalized and un-represented in the political arena could obtain the rights not guaranteed by the Government ${ }^{6}$. The reference highlights fairly well one of the recurring (and equivocal) issues in the discussion of the aforementioned litigation is the mistaken belief that the choice of virtuous magistrates in itself can promote the promotion of fundamental rights, but that to count on conservative judges could lead to undesired results, as if the functioning of the system depended only on the choice of the magistrate. However, this approach would be too reductive.

This assertion is based on the impossibility of making a complete analysis of the concepts of the theory of law (Habermas ${ }^{7}$, Gunther $^{8}$, Alexy $^{9}$, Dworkin $^{10}$, Waldron ${ }^{11}$, Hart ${ }^{12}$,

Vinodh Jaichand, Estratégias de litígio de interesse público para o avanço dos direitos humanos em sistemas domésticos de Direito, SUR - Revista Internacional de Direitos Humanos, 1 (2004), 134.

Yoseph Mulugeta Badwaza, Public Interest Litigation as practiced by South African Human Rights Ngos: any lessons for Ethiopia? At the Community Law Centre, Faculty of Law, University of the Western Cape (2003).

K.G. Balakrishnan, Growth of public interest litigation in India. In: Armin Rosencranz, Michael Jackson, The Delhi Pollution case: The Supreme Court of India and the limits of judicial power, Columbia Journal of Environmental Law, 223 (2003).

5 Jonathan T. Molot, An Old Judicial Role for a New Litigation Era, The Yale Law Journal, 113 (2003), 27.

6

It is worth of notice that the precedent was set by the great articulator, the newly appointed Justice Warren, who was able to convince his peers that the right to equality enshrined in the 14th Amendment did not constitute discrimination, as there are over 50 years has affirmed the Supreme Court in Plessy vs. Ferguson to establish the doctrine of "equal but separate". The President of the Supreme Court could not only revoke that precedent, but state that the decision was unanimous. This "activist" attitude of the Supreme Court, however, ended after the departure of Warren, and since 1980 the Court took a conservative stance. See Michel Rosenfeld, Les décisions constitutionnelles de la cour suprême américaine pour la session 1998-1999: redéfinir les limites du fédéralisme au détriment des droits indiviuels, Revue du Droit Public, 5 (2000), 1329.

7 Jürgen Habermas, Faktizität und Geltung: Beiträge zur Diskurstheorie des Rechts und des Demokratischen Rechtsstaats, Frankfurt, 1994. Jürgen Habermas, Verdad y justificación, Madrid, 2002. 
Posner $^{13}$, Garapon ${ }^{14}$, and others), or of public interest litigation, with its impacts, e.g. in socalled activists turover (as in India), without realizing the problems and peculiarities of the subject in our country, which could make the application of comparative law poor, and lacking in adequacy. It is important to stress this point because the methodological approach to these brief digressions from the perspectives and idiosyncrasies of our legal system, alters our perception of the challenges and most appropriate use of comparative law with a view to consolidating our democratic state of law. As we have said on other occasions $^{15}$, is no longer possible to make an accurate analysis of comparative law with occasional forays into the institutions, techniques or theories without promoting a macro-structural analysis.

Thus, the first step, prior to the actual comparison is to understand the Brazilian institutional framework and at this point, our problems are many.

Klaus Günther, The sense of appropriateness: application discourses. Morality and Law, New York, 1993. Klaus Günther, Justification et application universalistes de la norme en droit et en morale, Archives de Philosophie du Droit, 37, (1992), 269.

Robert Alexy, Balancing, constitutional review, and representation, International Journal of constitutional Law, 4 (2005). Robert Alexy, Teoria da Argumentação Jurídica: a Teoria do Discurso Racional como Teoria da Justificação Jurídica, São Paulo, 2001. Robert Alexy, Derecho y Razón Práctica, México, 1998.

10

Ronald Dworkin, Taking rights seriously, Cambridge, 1978. Ronald Dworkin, O Império do Direito, São Paulo, 1999.

Jeremy Waldron, A dignidade da legislação, São Paulo, 2003.

Herbert L. A. Hart, Conceito de Direito, Lisboa, 1994.

Richard A. Posner, Problemas de filosofia do direito, São Paulo, 2007.

Antoine Garapon, O juiz e a democracia, Rio de Janeiro, 2001.

As I said in another work of purely procedural approach "adopted comparative law analysis was grounded in the theoretical knowledge scaled by Damaska (1991) and Taruffo in their scientific work, though they did not seek verification of micro-problems to procedures (cuts) or various systems, but aimed to draw up comprehensive schemes of systems analysis procedure (Taruffo, 1991, p. 10) with the design of the main "process models" of modernity: liberalism and the socialization procedure. They introduced themselves thus, the main features and degeneration of these "models" in order to subsidize the defense of a participative perspective, starting from an "integrated comparativism" which realizes the importance of fundamental rights in all legal systems (Taruffo 2002b, p. 52). The old schemes of "family law" were not used (civil law vs. common law) or procedural systems (versus accusatory inquisition) reputed for a proper understanding of the complexity of the legal discussion of high modernity, especially in the procedural field, given the contrast between the territorial and globalization, resulting from tax multiculturalism and verification of "circulation of models" (Taruffo, 2002b, p. 25)"- Featuring Dierle José, Coelho Nunes, Processo jurisdicional democrático, Curitiba, 2008. 


\section{B. Crisis of the Institutions}

When analyzing the current use of judicialization in this country for the implementation of fundamental rights, we cannot ignore the fact that such a phenomenon is a consequence of a more serious problem: the crisis of the institutions of our country. We see a crisis in representative democracy and a Parliament with no agenda ${ }^{16}$. An Executive that does not promote the public policies necessary to guarantee fundamental rights, in fact, the public policies of the latter are concerned only with trying to divide public income, rather than with the achievement of the whole constitutional project of 1988 and the consolidation of policies of fundamental rights. The Constitution in our country often conforms to the holder of the "government". We have seen that with each new government the CRFB goes through a series of amendments to allow "governance" when it should dictate the grounds of public policy.The crisis of democracy has multiple factors. Marilena Chauí points out: the shrinking of public space and increase in private (because of neoliberalism), destruction of the sphere of public opinion, destruction of public discussion and debate (by political marketing, which offers ready solutions and is inescapable to a citizen-consumer), the ideology of power (by which the policy should be reserved for experts) and the means of mass communication ${ }^{17}$. Moreover, in this, we cannot deny the clear historical deficit that Brazil has over other countries due to its delay in adopting a constitutional culture.

Effective constitutionalization in Europe and the beginning of a period devoted to the jurisdiction ${ }^{18}$ began post-Second World War, with the decline of the Social State and the need for penitence and reconstruction in relation to the excesses that the Executive (distorted and totalitarian) had implemented, in our country the gains of constitutionalism and legal science as a whole, only arise in our discussion of the guidelines from the 1988 Constitution, in the face of "scientific isolation" that we are going through by numerous factors. And the shift of policy issues and enforcement of social rights in the Judiciary cannot omit

As Alexandre Bahia has stressed through the research group of the Law School of Minas South, in many countries such as Portugal, the Parliament at the beginning of each term, offers an agenda (schedule) and in the end, is accountable to what was voted for. In our country, we never know the object of interest of our Parliament. We must thus rethink the crisis of our institutions and the public institutional space. In this sense see Alexandre Bahia, Dierle Nunes, Crise da Democracia Representativa - Infidelidade Partidária e seu Reconhecimneto Judicial, Revista Brasileira de Estudos Politicos, 100 (2009), 57.

17 Marilena Chauí, O que é Política? In: Adauto Novaes (org.), O Esquecimento da Política, Rio de Janeiro, 2007, 27-28. Now if politics is the realm for discussion, and it doesn't happen, social and economic minority groups are the ones who are ultimately jeopardized since they are the ones, more than anyone else, who "feel the need to claim for rights and to create new ones". Marilena Chauí, O que é Política? In: Adauto Novaes (org.), O Esquecimento da Política, Rio de Janeiro, 2007, p. 52. If they cannot do it through the Parliament, their causes are going to end up at the legal system.

18 Nicola Picardi, La vocazione del nostro tempo per la giurisdizione, Rivista Trimestrale di Diritto e Procedura Civile, 58 (2004), 41. 
the perception of the last great legislator of the twentieth century, Lord Woolf ${ }^{19}$, who in the monumental English reform of 1998, said a huge amount of cash was wasted by the court system to settle disputes arising from a breach of fundamental social rights and that it would be better spent on securing public policies of health and housing (to give examples in the English situation) and to which one might add, in Brazil, numerous other fundamental rights not guaranteed to our citizens, rather than generating millions of actions in our judicial system.

\section{B.I. $\quad$ Crisis in the Judiciary}

We cannot forget the crisis of the judiciary. And this problem becomes one of the most serious when discussing the trend, after $\mathrm{CRFB} / 88$, of use of the judiciary as compensation for the deficits of the function of other Powers ${ }^{20}$. Let us not forget that when we enter the "new" constitutionalism, Brazil devotes, more than ever, access (wide) to justice as a fundamental right ${ }^{21}$. It is known that under the framework of tripartite functions if any of them fails, effectively, its institutional role, there is a systemic compensation which in our country tends to be attributed to the judiciary.However, our judiciary, not even through an immense effort of his organs, could be "virtuous" in the face of demands for productivity and number of procedural maximum speed. In Waldron, we must realize that we "build (...) an idealized portrait of the judge and frame it along with the image of the bad reputation of legislating ${ }^{22} "$ and, in the face of this, we must rethink our legal position and the romantic speeches of virtue and sensitivity of our decision-makers, under the risk of being labelled as an idyllic "judicial activism" to implement a true juristocracia.

In the field of procedure and the enforcement of rights, we know that we moved from the perspective of procedural liberalism, which is characteristic of the eighteenth and nineteenth centuries, to the perspective of the socialization process in the twentieth century, and that this was aimed, according to a prestigious teaching ${ }^{23}$, at the acceleration of the process with a rapid restoration of legal peace, but without imposing the omnipotent state on the field of process with the help of the judge.

Harry Woolf, Final report to the Lord chancellor on the civil justice system in England and Wales - July 1996. Access to justice, London, 1996.

Alexandre G. Melo Franco Bahia, Recursos Extraordinários no STF e no STJ: conflito entre interesses público e privado, Curitiba, 2009, 293 et seq.

21 On this intimate relationship between access to justice in Brasil and democracy, refer to Boaventura de Sousa Santos (et. al), Proposta de projectos para o Observatório da Justiça Brasileira, Coimbra, september 2009, 5-8.

Jeremy Waldron, A dignidade da legislação, 2003, 2. Obviously, we should also criticise some of their judicial self-restrictive conceptions. 
The theoretical contributions of this new role of the judiciary ${ }^{24}$, which should compensate for the shortfalls of material equality in society with a consequentialist role (a preview of the impacts of decision-making on the political, economic and social spheres) were inaugurated, among others (despite having won the highest penetration in post WWII society) in the doctrine of the Austrians Klein ${ }^{25}$ and Menger ${ }^{26}$. These doctrinal considerations, typical of the last decades of the nineteenth century and early decades of the twentieth century portrayed an attempt to combat the extremely formal process where the role of the judge was reduced to a mere spectator figure, typical of the liberal state. After WWII, and as a result of the structuring of the constitutional courts as outlined above, a new impetus was given to judicial activism conceiving the role of judge as the role of guarantor of promises and social engineer. It is also worth mentioning that some of the supporters of the ideal of a process with this remarkable social function and without normative neutrality believe that the judge acts as an active channel for communication with an axiological load of the current society in which they live, as well as the normative texts ${ }^{27}$, and the interpreter has a sensitivity in the solitary pursuit of the common good.

However, as Habermas also notes, we can see the error of credulity in the existence of a concrete and universally binding ethos of a more or less homogeneous community ${ }^{28}$, especially against a backdrop of pluralism of worldviews, because in this we see the possibility of rational dissent about standards of fundamental value ${ }^{29}$, preventing a lone subject, body or entity becoming, themselves, the values of the community. Only speech which is guaranteed by the autonomy of citizens in a public space structured by procedural constitutional guarantees (principles), allows cooperation ${ }^{30}$ and adequate appointment of suitable persons ${ }^{31}$.

Cf. com maiores elementos: Dierle José Coelho Nunes, Processo jurisdicional democrático, Curitiba, 2008.

Franz Klein, Zeit- und Geistesströmungen im Prozesse, Frankfurt am Main, 1958.

Anton Menger, L'État socialiste, Paris, 1904. Anton Menger, El derecho civil e los pobres, Buenos Aires, 1947.

Cf. Cândido Rangel Dinamarco, A instrumentalidade do processo, 2001, São Paulo, 294. For the group coordinated by Luiz Werneck Vianna, the Federal Supreme Court would have the ethical pedagogical mission of signing how and why society should be tranformed, enforcing form top to bottom the Fundamental Rights. Cf. Luiz Werneck Vianna (et al), A judicialização da política e das relações no Brasil, 1999, 146. In the same sense José Eduardo Faria, As transformações do judiciário em face de suas responsabilidades. In: José Eduardo Faria (Org.), Direitos Humanos, Direitos Sociais e Justiça, 1998, 62.

Jürgen Habermas, Direito e democracia: entre facticidade e validade, 1997, t. I, 129.

Jürgen, Habermas, Verdad y justificación, Madrid, 2002, 290.

30

Jürgen Habermas, note 28, p. 163.

31 Important in this respect, procedural discourse, is the theory presented by Elio Fazzalari, celebrated in 1958 in Perugia where, following the line of reasoning of Benvenuti, he states the process is a more complex scheme of procedure. This differed from the procedure of this process 
Therefore, the understanding that working with a separation of roles within the procedural framework becomes the unacceptable, having the judge in one side of the court as a third party, with privileged access to what would be the common good, and on the other side, parties who would be jettisoned from procedural discourse, delivering their legal interests to the criterion of "common good" of this judicial body ${ }^{32}$. It is important to implement an accurate and inclusive procedural debate so that the maximum information is gleaned, and informed decisions are rationally reached, especially when discussing the application of a fundamental right. And the problem of the crisis of the judiciary not only includes the problem of reasoning, but must also take into consideration the discussion of efficiency $^{33}$.

As Taruffo notes, there are at least two types of efficiency in the judicial and procedural system $^{34}$.

by the existence of a dialectical structure that allows the participation of stakeholders at the preparatory stage of filling (the decision). This was permitted, thus ensuring symmetry of subjective positions of any of the participants in the process of dialogue and the possibility of exercising a controlled set of reactions and choices within this structure. It is thus the standard process as often predisposes to the completion of an activity the dialectical structure that allows those interested to participate to the stage of recognition of the assumptions about the condition of reciprocal and symmetric parity, i.e. have the process visible at every point in time. Cf. Dierle José Coelho Nunes, Processo jurisdicional democrático, Curitiba, 2008 and Elio Fazzalari, Diffusione del processo e compiti della dottrina, Rivista trimestrale di diritto e procedura civile, 3 (1958), 861. The beginning of this theory could be found in: Elio Fazzalari, Note in tema di diritto e processo, Milano, 1957.

Jürgen Habermas, note 29, p. 295-296.

"And indeed there is ubiquitous concern with increased efficiency. In the midst of this concern, a tendency is discernible to deemphasize preoccupations with procedural form - including residual differences between common law and civil law regimes-and concentrate instead on measures likely to contribute to the efficient functioning of civil justice. But consider that efficiency, properly understood, is a measure of the relation of the valued output, or goal of an activity, to the cost of achieving it. The speed and cost at which a justice system disposes of ingested cases tell us little about its efficiency unless we are informed of its goals: without reference to them, efficiency is a contentless ideal. Now, it would be wrong to believe that goals and value systems of more or less bureaucratized machineries of justice are alike. Their assessments of the importance of accurate fact-finding, consistency in decision-making, dissent, official discretion, or the outsourcing of official action, all differ in significant ways. Thus, so long as vestiges persist in civil procedure of attitudes traceable to disparate common law and civil law structures of authority, they should not be disregarded, even if one's principal concern is the increase of procedural efficiency. Nor is it really passé, for the purpose of rough orientation on a number of procedural issues, to keep in mind that continental civil procedure retains remnants of procedural attitudes and arrangements congenial to a hierarchical-bureaucratic machinery of justice, while its common law counterpart keeps alive vestiges of a more egalitarian and less bureaucratized institutional environment". Mirjan Damaška, The Common Law-Civil Law Divide: Residual Truth of a Misleading Distinction, in: Federico Carpi, The future of categories. International Association of Procedural Law, Toronto, 2009.

34 Michele Taruffo, Orality and writing as factors of efficiency in civil litigation. In: Federico Carpi, Manuel Ortells, Oralidad y escritura en un processo civil eficiente, Valencia, 2008, 185 et seq. 
The first perspective of efficiency, the quantitative, is defined in terms of procedural speed and cost reduction, where the more inexpensive and quick the resolution of conflicts, the greater efficiency that would be obtained, and the quality of the procedural system and its decisions a factor of lesser importance ${ }^{35}$.

The second perspective of efficiency (qualitative) is that in which one of the key elements of its implementation would be the quality of decisions and their reasoning and this would lead to the need for adequate, accurate, fair, equitable ${ }^{36}$ and, as should be added, democratic procedural techniques for law enforcement.

As Taruffo emphasises, both perspectives would be as sides of a coin, but they can, and often are, seen as contradictory conceptions as 'fast and cheap' can form incomplete or incorrect decisions, while a decision to search for "fair" (correct and legitimate) requires money, time and great effort shared between the judge and other procedural subjects. Such a situation, in these terms, it is usually important to choose one type of efficiency and completely exclude the other ${ }^{37}$. Unfortunately, due to numerous factors, the Brazilian court system often works with quantitative efficiency, even imposing a neoliberal ${ }^{38}$ vision of high productivity and uniformity of decisions, and the superficial understandings of the courts ${ }^{39}$,

Michele Taruffo, note 34, p. 187.

Michele Taruffo, note 34, p.188.

Michele Taruffo, note 34, p.188.

Dierle José Coelho Nunes, Processo jurisdicional democrático, Curitiba, 2008.

One cannot neglect in this aspect, the important considerations in the Minister Benjamin Herman, on the dangers of uniformity without a previous thorough discussion of the issues, see: "A political and procedural initial puzzlement, solving conflicts through collective action of civil individual reflex and destruction of the right of access to justice for millions of consumers. The First Class colenda decided on 24.4.2007 (fl. 186), to affect this demand to the first section. So far, nothing unusual, because often repetitive or complex issues are brought to the college of ten States to which its members may have decided them in a uniform manner, thus avoiding divergent understandings between the two classes. Here, however, arise peculiarities that discouraged such "affectation" as and when it was done, almost automatically, without any prior discussion and maturation in the domestic sphere of both classes, of the many new and controversial issues that accompany this demand. The complex issues involved in the process - and they are many, as we will see during this work - have not undergone the scrutiny of previous discussions between the members of classes, these debates need to identify and clarify the main disagreements and conflict of this size, which, although conveyed by individual action (and formally refer exclusively to a single consumer), affects, directly, more than 30 million subscribers (rectius, consumers). Difficult to deny that under the Supreme Court, the demand was not ripe for the prolate in unifying and standardizing the decision to direct the section, its two classes and all courts of Brazil. In disputes of this magnitude, involving millions who are under jurisdiction, it is essential to preserve the technical and rhetorical space for broad exposure, careful research and meticulous dissection of the issues raised herein or that may be raised. Otherwise, it will restrict the healthy debate and thwart the will of the adversary system, so necessary for the foundation of a good and safe decision of the board of decisions. It is true that the internal rules provides for "affectation" of cases to Section "because of the relevance of the legal issue or the need to prevent differences between the groups" (art. 127). However, we chose just a single action, a contractor from Rio Grande do Sul, 
even if this occurs before a thorough debate on cases, in order to increase the statistics in terms of a case being "resolved."

We have arrived at the situation now where the National Council of Justice has created productivity goals (Goal 2, 2009 $9^{40}$ and $2010^{41}$, for example) and these have then been placed on their website, via a "processômetro" to indicate the productivity index of the Brazilian Courts ${ }^{42}$. This leads to the judges of first degree jurisdictions and the Courts are relegated to the role of robots by the Superior Courts by means of the system of setting agendas and the consequent decision-making pattern, so much so that they are compelled

triply vulnerable within the meaning of the constitutional welfare model 1988 - consumer, poor and black - to set the precedent imposing uniformity, even knowing of the existence of several public civil actions, on the same subject, that move across the country. That is, it reversed the logic of collective civil procedure: instead of performing public civil action res judged erga omnes, is that individual action, by an expedient procedure of the Court, of a pragmatic nature, in fact becomes, in consequence standardizing the effectiveness of collegial decision, an instrument of conflict resolution and collective commoditized. Do not resist the temptation to point out here the paradox. While the national legal system denies the consumer-subject, be vulnerable, standing to the commencement of public civil action (Law 7347/1985 and CDC), the Supreme Court, by the back door, you agree that an individual demand - legal and procedural environment favorable to the prevalence of the interests of the subject super powered (in casu the telephony service provider) - will play the role of public civil action in reverse, because the provision in favor of the company will rise to kill thousands of assimilated demands - both individual and collective. Indeed, in his Memorials, was precisely that one of the arguments (the avalanche of individual actions) used by the utility to justify an immediate intervention of the Section. Finally, he was elected just a consumer demand for poor and black (as we said above, triply vulnerable), lacking financial resources to be present physically in the Supreme Court, by filing of briefs, hearings with Ministers and oral argument. As a judge, but also as a citizen, I cannot but regret that in the argument (?) Before the oral section and also visits to offices, real monologue of the largest and best law firms in the country, the voice of consumers has not been heard. I regret not only the silence of D. Camila Mendes Soares, but rather the absence in oral arguments, representatives of the interests of litigants shadow highlight [...]" - BRAZIL, STJ, 1H, Resp. 911.802/RS, Rep. Min Jose Delgado, j. 24.10.2007, DJe. 01.09.2008.

40

"Identifying the earliest lawsuits and adopt concrete measures for judging all distributed to 31/12/2005 (1st, 2nd degree or higher courts)" until the end of 2009. See www.cnj.jus.br Accessed 10/07/2009.

41

"The new Target 2 is more comprehensive than the one established last year, since it contemplates all cognitive proceedings assigned (first instance, second instance and superior courts) until December 31st 2006 and for labor, electoral, military and jury trial cases, until December 31st 2007. Targets 1 and 3 also tried to reduce the burden of suits, accelerating and making the legal services more efficient. Target 1 consists of judging in 2010 a quantity equal to the number of processes distributed this year over a portion of the accumulated actions. Target 3 , in turn, aims to reduce at least $10 \%$ of the collection process at the stage of enforcement or implementation and $20 \%$ of the pool of foreclosures." Cf. <http://www.cnj.jus.br/index.php?option=com_content\& view $=$ article $\&$ id $=10350 \&$ Itemid $=1125>$.

42 Note that here we do not present any rebuke to the search for accelerated constitutional processes, but the reduced efficiency of the system in a frantic search for speed at any cost to counter the ideas shallower than is meant by a democratic process. 
only to repeat them without having the least means to render decisions considered and forged in procedural debate.

\section{B.I.1. Diversity of litigiousness: the tendency to standardize decisions}

Especially in the face of the expansion of the agenda of the Brazilian judicial system, we know that it is not possible, at present, to forget that legal science (and procedure) needs to deal, with a view to achieving a legitimate and efficient application, with three types of litigation: (a) individual or "retail" in which the study and dogma were traditionally developed, involving injuries and threats to individual rights, (b) the collective litigation, involving collective and diffuse rights, which are used in collectively represented procedures, usually sponsored by a legitimate extraordinary body (implementation of MP, Representative Associations etc.) and (c) mass or high-intensity instances, giving rise to the commencement of serial or repetitive actions, which are based on isomorphic claims, with specific differences, but which have common issues (legal and/or factual) to resolve ${ }^{43}$.

This issue of litigiousness should be placed under discussion in Brazil, however, without losing the focus of the judiciary on the trial of causes, not theses. For some time the reforms have focused on the attempt to unify the law at all costs. The assumption is that it is possible to establish "standards of interpretation" from the prosecution of some cases, a Court of "higher rank", given the multiplicity of cases, the judge is to ignore their specifics and take into account only the "theme" or the "theory" behind it. After the definition of the "thesis", all other cases will be judged based on what was predetermined; meaning that the specifics of these new cases will also be disregarded in order to concentrate only on the "thesis" that makes them identical to previous cases 44 .

Humberto Theodoro Júnior, Dierle Nunes, Alexandre Bahia, Litigiosidade em massa e repercussão geral no recurso extraordinário, Revista de Processo, 177 (2009), 20. Cf. Sergio Menchini, Azioni seriali e tutela giurisdizionale: aspetti critici e prospettive ricostruttive. In: Atti del Incontro di Studi: le azioni Seriali do Centro Interuniversitario di Studi e Ricerche sulla Giustiza Civile Giovani Fabbrini, Università di Pisa, 04-05 may 2007.

Cf. Alexandre G. Melo Franco Bahia, Recursos Extraordinários no STF e no STJ: conflito entre interesses público e privado, Curitiba, 2009, 175 e 310. On pg. 175 it is said: "The mechanism of this dismissal of certain features is "identical" while some of them are heard by the Court (and later the decision predetermines the fate of these too), we can only express our perplexedness: the belief that the issues in law can be treated as "certain", and that one can really say that the causes are identical; in handling cases such as standards, or such as themes, since the characteristics of the case and claims that are raised in each one are ignored and then one of them will try to make the tribunal aware of the importance the assessment of the court. If this comes to pass, all other resources will perish, without which there will have been no individual assessment, whereas if if this does coem to pass, all others will be judged in the same way, also without an individual assessment."And on pg. 310:"The treatment of cases together, the assumption that different causes may converge around themes (because the causes are identical) can only happen on certain assumptions: the belief that one application of the law can be done simply, mathematically almost - tied to an understanding of conceptions not overcome at least since Kelsen (not to mention Gadamer)." See also, Alexandre G. Melo Franco Bahia, Os Recursos Extraordinários e a Co- 
There is much talk on the need for ensuring "equality", that is, we must seek the establishment of uniformity in decisions, because the fact that there is even disagreement on a "theme" violates the constitutional guarantee of equal treatment for all. But what is equality? We know that long ago ceased to be only a negative concept, as it was in the eighteenth and nineteenth centuries and came to include also a positive dimension (the right to difference $)^{45}$. Thus, equality is preserved when, faced with similar situations, there are similar decisions. However, contrary to the same principle in cases where situations are "similar" 46

originalidade dos Interesses Público e Privado no interior do processo: reformas, crises e desafios à jurisdição desde uma compreensão procedimental do estado democrático de direito, in: Marcelo A. Cattoni de Oliveira, Felipe D. Amorim Machado (coord.), Constituição e Processo: a contribuição do processo no constitucionalismo democrático brasileiro, Belo Horizonte, 2009, 366-369. There it states: "The Supreme Court, as the Supreme Court, do not advocate the thesis, they judge. It results not from the activity of a thesis but a ruling" (p. 366, bold in original).

Alexandre Bahia, Dierle Nunes, O potencial transformador dos direitos privados no constitucionalismo pós-88, Revista dos Tribunais, 882 (2009), 45.

This question, regarding the difference between "identical" and "similar"cases is of paramount importance today, given the existence of technical repercussions in general, and special repetitive features and how they are being applied by the STF and STJ. Both techniques are born with deficiencies of application, among them, checking whether the resources chosen (representative of the controversy) cover only identical cases, or whether they are also being used wrongly, hindering the prosecution of similar cases, and if such a mistake occurs, the mechanism to submit the dispute to the Supreme Court? In a recent article, we advocated the appropriateness of interlocutory appeal of art. 544, CPC (current grievance in the case, after the law reform 12.322/2010). Humberto Theodoro Júnior, Dierle Nunes, Alexandre Bahia, Litigiosidade em massa e repercussão geral no recurso extraordinário, Revista de Processo, 177 (2009). Others tried to enforce this in practice complaint. However, the Supreme Court decided, "claim. alleged inappropriate use by the chair of the court of origin of the office of the overall impact. decision given by the plenary of the supreme court of appeal judgement in federal special issue $576.336-\mathrm{rg} / \mathrm{ro}$. allegation of jurisdiction misused the supreme court of federal and summary affront to the fts 727 . inocorrência. 1 . If no court of admissibility of extraordinary resources, it is not suitable for bringing an interlocutory appeal under art. 544 of the Code of Civil Procedure, which is why there is no need to speak in outrage of Precedent STF 727. 2. The plenary session of this Court decided in the trial of Preventive Action 2.177-MC-QO/PE, that the jurisdiction of the Supreme Court only starts with the maintenance by the Court of origin, contrary to the decision understood as signed at the trial of the impact generally pursuant to $\S 4$ of Art. 543-B of the Code of Civil Procedure. 3. Outside of this specific case there is no legal appropriateness of an appeal or other legal remedy to the Supreme Court. 4. Intelligence arts. 543-B of the Code of Civil Procedure and 328-A of the Internal Rules of the Supreme Court. 5. Chance of a party which considers the erroneous application of general repercussion to bring a grievance procedure before the Court of origin. 6. Opportunity to fix, the very scope of the Court of origin, is in court to withdraw, either by collegial decision, the possible misunderstanding. 7. Not knowing of this complaint and appeal of the injunction previously granted. 8. Determination of sending the case to the Court of origin for processing such as grievance procedure. 9 . Authorization of the Secretariat of the Supreme Court to proceed with the immediate low this Complaint." (STF, pleno, rcl n. 7569/sp, relatora min. ellen gracie, j. 19/11/2009). to similar effect, the sTJ is expressed by saying it would fit the bill of review provided for in art. 544 of CPC against the decision of the President or Vice-President of the court of origin that determines the dismissal of the special appeal made to the rite of art. 543-C of the CPC (STJ 2nd T., No 1.223.072/SP AgRg in Ag, Rep. Min Humberto Martins, j. on 09.03.2010, published in the 
there applies, without further investigation, a "thesis" defined above (without consideration of issues specific to the case being decided and the paradigm, cf. below): also there is no violation of equality, in this second sense, as a constitutional right to difference and uniqueness ${ }^{47}$. In these terms the issue becomes more complex, since it is no longer possible to simplify the issue as only aiming to solve the efficiency problem quantitatively, from the assumption of an outdated interpretation that represents the current conception of equality, because equality and difference will be co-originating in the formation of equality.

The tradition of the precedents ${ }^{48}$ of the common law countries may thus be well utilized for this debate in relation to equality, to avoid the earlier criticism held that it can be seen

03/18/2010 DJE). The court stated incabível be cautious: "The group did not know of the injunction which sought to process the special feature that, according to the applicant, had been wrongly suspended by the court in the manner of art. 543-C, $\S 1$ of the CPC. According to Min Reporter, the direct analysis of the adequacy of the matter treated in the special appeal, and that versed in resource and representation, pointed to the conclusions that the dispute would be possible only in exceptional cases, after the initial trial of this representative and its subsequent submission to the collegiate responsible, that has not happened in similar cases. He asserted that the decision of the local court determines that the suspension is alluded to, in principle, without appeal, being the STJ carry it on a deferred control, embodied in the initial examination. It is affirmed that the admission of any form of insurgency that seeks to reverse the dismissal of the special appeal in terms stipulated by art. 543-C of the counter CPC systematic brought by Law 11.672/2008 and the precepts of reasonable duration and speed the process of adjudication. Previous cited: Rcl 3652-DF, DJE 4/12/2009. MC 17226-RJ, Rel Min Massami Uyeda, judged on 5/10/2010. (STJ, MC 17226RJ, Rel Min Massami Uyeda, J. 05/10/2010) "Informativo STJ -450 04 to 08/10/2010. It remains, then, the appropriateness of the aforementioned, by vote of Min Ellen Gracie, "grievance procedure" in the court of origin, where the jurisdiction would be in the Superior Court. We must, however, question this understanding and putting into question the techniques themselves, so they are not used only to resolve the operational problem of the Superior Courts when they are judging the major legal issues and enforcement of fundamental rights in our country.

47 We have to consider that there are moments that should prevail in the process of "metaphor" in which differences can be neglected and the court concentrates on the similarities and also moments of "metonymy," where, on the contrary, the context and singularities will prevail. Knowing when is the case with one another, or even both (to some extent) can only be defined in the decision of the case. For more on this view see Michel Rosenfeld, The identity of the constitutional subject, Cardoso Law Review, 16 (1995), 1069.

As Whittaker states: "[...] la trascendencia y autoridad tradicionales otorgados a los casos fallados ("precedentes" en el amplio sentido identificado por John Bell) por los juristas ingleses (y, notablemente, jueces posteriores) fueron reforzadas durante el siglo XIX mediante un conjunto de normas en cuya virtud una sentencia anterior (o, al menos, parte de la misma, su ratio decidendi) fue declarada formal y jurídicamente vinculante para un tribunal posterior. Este conjunto de reglas devino conocido como la doctrina del precedente u ocasionalmente stare decisis (precedente en el segundo sentido señalado por John Bell)". Simon Whittaker, El precedente en el derecho inglés: una visión desde la ciudadela, Revista Chilena de Derecho, 35 (2008), 37. 
as a "formula for the perpetuation of error ${ }^{49}$." Whittaker tells how, in the English tradition: ${ }^{50}$

[...] the starting point of the Common Law means that the nature of the materials that build on the many English judgments differs radically from those legal systems which are based on legislation. Indeed, the place to start is not found in a single text - whatever its length or inaccuracy - but in different texts, i.e. the reconstruction of decisions covering a period that often goes back two centuries and sometimes periods larger. Likewise, the class of the text of an English sentence is fundamentally different from all the legislation, and that for regular or argumentative mode of discourse, in which the judge or judges weigh the considerations of race in prior cases to reach its decision. Even if a judge seeks to expose the law in one or more propositions, these words alone, lack all force except (inter alia) in their respective legal and factual sense. This reaffirms the idea that previous resolutions are not simple touches off a wider context (although an English jurist must always go back to enjoy an area of law), because the texts of the judgments aspire for themselves what their relationship occurred with before and, in some instances, what may happen later. Certainly, more recent decisions ("discourse") of the members of the House of Lords seeking to outline the model of legal propositions concerning the type of subject matter to their knowledge, giving meaning to the number of previous decisions.

In these terms, one realizes that even in countries where the use of precedents is traditional, it can be done mechanically without the use of historical reconstruction and decisions may be implemented without discussing their adaptability, even though one may seek this aim based on a narrow logic of implementation of equality ${ }^{51 .}$

49

50

Simon Whittaker, note 48, p. 38.

Originally: "[...] el punto de partida con el Common Law significa que la naturaleza del material sobre el que se construyen muchas decisiones judiciales inglesas difiere radicalmente de aquellos sistemas jurídicos cuya base es legislativa. En efecto, el lugar de inicio no se halla en un texto único - cualquiera sea su extensión o vaguedad - sino que en diversos textos, esto es, en una recopilación de sentencias que abarcan un período que con frecuencia se remonta dos siglos atrás y a veces más. Asimismo, la clase de texto de una sentencia inglesa desde luego se distingue fundamentalmente de todo texto legislativo, siendo aquel por lo regular discursivo o argumentativo, en el cual el juez o los jueces sopesan las consideraciones en pugna identificadas en los casos previos para alcanzar su decisión. Incluso, si un juez busca exponer el Derecho en una o varias proposiciones, estas palabras, por sí solas, carecen de toda fuerza, salvo (inter alia) en su respectivo contexto jurídico y fáctico. Esto reafirma la idea de que las resoluciones anteriores no son simples toques en un cuadro puntillista más amplio (a pesar de que un jurista inglés siempre debe retroceder para apreciar uma área del Derecho), porque los textos de las sentencias intentan explicar por sí mismos su relación con lo que ha ocurrido antes y, en algunas oportunidades, con lo que puede suceder con posterioridad. Ciertamente, muchos más fallos recientes ("discursos") de los miembros de la Cámara de los Lores buscan delinear el modelo de las proposiciones jurídicas que atañe al tipo de asunto sometido a su conocimiento, confiriendo sentido a las diversas decisiones anteriores." Simon Whittaker, note 48, p. 44.

As remembered by Whittaker: "[...] el proceso de decisión judicial inglés se revela como mucho más complejo que lo que la descripción formal de la doctrina del precedente sugeriría fácilmente, toda vez que los jueces procuran dirimir la tensión que existe entre las virtudes de la coherencia y la igualdad que subyacen al stare decisis y la necesidad de adaptar el Derecho para hacer justicia a los hechos que evolucionan ante sí.” Simon Whittaker, note 48, p. 77. 
The defense of this "pseudo-equality" to increase efficiency (quantitative), to promote predictability by crystallization of positions (in the face of the fact that the Brazilian system requires the application of law to judges), encouraging a hierarchical design (rather than based on the division of powers of the Judiciary - breaking of judicial internal independence) and to discourage access to justice (which is the fruit of a historic struggle, and is becoming a functional problem, the lack of an effective reform of the judiciary and a suitable apparatus for that reform) should be themed with caution. We can no longer think only of the consequences (demands in profusion) from the institutional point of view the legal system would work better if causes were prevented (such as non-compliance with fundamental social rights etc.). And within that tone, one of the most tormenting questions is the tendency toward technical mechanisms for standardization of decisions for solving serial quantitative demands. Techniques of trial injunction ( $\S 1$ of Art. 518 and art. 285A, 317 of the current CPC and PLS 166/2010) such as overviews ${ }^{52}$, general repercussions ${ }^{53}$, repetitive appeals to superior courts, repetitive law suits incident resolutions ${ }^{54}$, show that search by way of an exegete assumption, to standardize decisions by default behaviours will not and cannot (as the great codes of the nineteenth century failed also to do) describe and regulate the world in text (before the Codes, today's standard decisions). And here we must point out, not to deny the phenomenon of convergence of systems (common law and civil law), but to understand it, adapt it and apply it in an efficient and legitimate (effective) manner in our country, with an accurate look at our unique features - and learning from the mistakes and successes of the experience of other countries.

\section{B.I.2. A new School of Exegesis?}

The Exegesis was a stream of legal thought in the nineteenth century which believed that the clarity of legal texts and legal security that this ensures. A central tenet of the belief was that of the absolute power of reason, which, shared by all, become the obvious standard mode of behaviour. This was developed to the point that standards (temporary and imperfect) should be in accordance with the eternal laws of reason (natural law). The process of positive law was nothing more than an attempt to translate the eternal laws of reason into positive laws. The idea of abstract and general rules is one of the greatest achievements of law in modernity: Laws are no longer made in order to secure privileges (of nobles and the clergy), for maintaining caste or, generally, to prevent social mobility. They now are a product of reason, equally shared by everybody, and therefore being hypothetical imperatives of behaviour, both general and abstract, that stabilize possible expectations of behav-

PEC. No 358/2005 wants to institute the Restriction of the resources to the Supreme Court and the TST would have the power to edit Precedents that would prevent not only immediate access, but also bringing any resources and other means of appeal against the sense of meaning.

Humberto Theodoro Júnior, Dierle Nunes, Alexandre Bahia, Litigiosidade em massa e repercussão geral no recurso extraordinário, Revista de Processo, 177 (2009).

54

Humberto Theodoro Júnior, Dierle Nunes, Alexandre Bahia, note 53, p.127. 
ior and that, therefore, resist noncompliance. Thus, when France adopted the French Civil Code of 1804 , they set out a law that was as perfect as the laws of natural justice. This code comes with the belief of being a complete and finished work, on which there would be no need for interpretation by the judge because every rule has a true, clear and obvious sense. The judge ought to stand in front of the standard of perfection, as one who utters the words of the law as the "bouche de la loi." ${ }^{55}$ Given the clarity and completeness of the rule, any issue concerning obscurity or contradiction would stem from a misunderstanding by the person applying the law, who therefore should consult with the legislature - "référé legislative". Doctrine further elaborated that the exegete, legal positivism, also the product of the nineteenth century, has developed more elaborate methods and techniques of law enforcement. The methods of interpretation were seeking a way to eliminate ambiguities, antinomies or anomie (all always apparent). Against anomie, there were methods of heterointegration and auto-integration of the right in question where, with the use of analogy and extensive interpretation, general principles of law, morality (etc.) obtained the applicable rule. Against antinomies, it resorted to the three rules: "lex superior derogat legi inferiori; lex posterior derogat legi priori; lex specialis derogat legi generalli". As for the obscurities, in the nineteenth century methods were being developed, one after another, to try to get the "true meaning" of the law. That is when there was doubt, interpretation was only required when the rule was not clear, since in claris cessat interpretatio. The main methods were: grammatical / literal, which assumed that the problem of obscurity is one that is solved by making use of a dictionary, this method followed logical, historical, systematic and teleological path. A "mens legislatoris" situation was sought, that is, to understand the duty of the law would result in what would have been the legislature's intent when drafting it ${ }^{56}$. Later, as this technique was increasingly viewed as flawed, there was talk of the search for "mens legis", that is, that one should seek the intent of the act in the law itself - including the facts and discussions that prompted it. In the twentieth century such methods and understandings have become outdated or at least problematic. All methods assumed the

According to Montesquieu, "les juges de la nation ne sont que la bouche les Thurs prononce paroles de la loi, des êtres inanimate Thurs n'en peuvent ni la force ni moderate la rigueur". Charles de Secondat Montesquieu, De l'esprit des Lois: Defense de l'Esprit des Lois, 1926, Book XI, Chapter 6. To Calamandrei, the judge does not even need to have eyes to see: he is an inanimate mechanism, a kind of spokesperson through which the law speaks for itself, the 'bouche de la loi. " And: "The judges, to work with the scalpel of the law, must forget the pain it inflicts on the cutting patients". Piero Calamandrei, Eles, os Juízes Vistos por um Advogado, Porto Alegre, 1997, 244 and 265. This could still be seen in a vote of the judges of the STF in the HC trial. 82424, FTS: for the Minister, since the constitutional provision that deals with racism in the text was inserted by amendment of two black constituents, so it is clear that the "will" of the legislature was to protect only blacks against racism.

56 This could still be seen in a vote of the judges of the STF in the HC trial. 82424, FTS: for the Justice, since the constitutional provision that deals with racism in the text was inserted by amendment of two black constituents, so it is clear that the "will" of the legislature was to protect only blacks against racism. 
Cartesian logic of science based three pronged approach; subject (neutral), object and method. Thus, the belief was that with the use of this method to solve the problem of legal interpretation, the hidden truth would be discovered. But what became clear is that the law, whether general and abstract, is not immune to manipulation and distortion (or even that, as outlined in the text, it is not immune to the hermeneutic condition that constitutes us). ${ }^{57}$

Discussion around this begins with Hans Kelsen, for whom the standard is not law, but 'the sense that is taken from a law' ${ }^{, 58}$. From that, Kelsen builds his Pure Theory of Law, which culminates in a theory of legal interpretation that it is worthwhile to highlight. Kelsen rejects the old ways of interpreting the law, since it makes no sense to seek a "mens legis" or "legislatoris" "59 . At the same time, those methods (grammar, logic, etc.) suffer from a problem concerning their suppositions, that to say they still believe in finding the (unique) true meaning to the rules, when in fact it does not exist. On the contrary, Kelsen argues that all standard are open to a framework of possible interpretations (all equally valid, without any relation of priority between them), completed by the doctrine (nonauthentic interpretation) and to which can also be added the courts. It is for the legislature and the judge (authentic interpreters), to produce, respectively, the general rules/abstracts and individual rules, within the framework provided ${ }^{60}$. In fact, the authentic interpreters, because they receive permission to decide from a higher level, can therefore give decisions that are entirely outside the framework, under extra-juridical grounds ${ }^{61}$.

Realise, then, that anyone who advocates, today, univocal or "clarity" on legal interpretation (whether a law is a Precedent) falls short of Kelsen's theory from the middle of last century. Since Kelsen, the postulates of exegesis and even classical positivism as "a" true or correct meaning of a standard, no longer make sense. Similarly one cannot ignore the contributions of the "Philosophical Hermeneutics"; with Gadamer we see that any doctrine or legislation concerning judicial decision making can no longer postulate that the application of law can be given in the manner proposed by the classical positivism. Just to start with, because it is no longer possible to establish a dogmatic belief in the method, in the belief that a neutral subject, detaching from a portion of reality will treat it through a "rigorous" method. For Gadamer, there isn't a method of "a priori" knowledge valid for all cases, but only methodological constructions to be built and justified on a case by case basis $^{62}$. There is no neutrality in science, nor in law enforcement, there are no methods or

Alexandre Bahia, A interpretação jurídica no Estado democrático de Direito: contribuição a partir da teoria do discurso de Jürgen Habermas. In: Marcelo A. Cattoni de Oliveira (Coord.), Jurisdição e hermenêutica constitucional, Belo Horizonte, 2004, 301-357.

Hans Kelsen, Teoria Pura do Direito, São Paulo, 1987, 4.

59 Hans Kelsen, Sobre a Teoria da Interpretação, Cadernos da Escola do Legislativo, 5 (1997), 36.

60

Hans Kelsen, nota 58, p. 394. tucional, Belo Horizonte, 2001, 39.

Hans-Georg Gadamer, Verdade e Método - II, São Paulo, 2002, 457. 
methodological constructions that want to relieve us of the "problem" of "having" to interpret from the preset direction. Gadamer shows how three original actions/moments that, until then, had distinct/repeated: comprehension, application and interpretation: there is no such clarity in a text that it can be dispensed from the interpretation, understanding a text (of a fact) is always, at the same time, interpreting, applying a standard solution and a case - both "texts" - involving both their understanding and, therefore, their interpretation ${ }^{63}$. The human condition is a hermeneutic condition, so any judge before a case will - ontologically immovably - interpret facts, rules, evidence and arguments. Instead of neutrality, we will speak now of impartiality, that is, considering that it is not possible that the magistrate could "leave the world" to decide the case - if, we assume, the limits of language are the limits of the world ${ }^{64}$ - we should explain in detail the reasoning that formed his "conviction". Although there is no difference between interpreting a text and a standard, Gadamer ${ }^{65}$ points out different goals between the first, which is historically understood and the second, which is a hermeneutic process which seeks to achieve the standard context of the case, as a rule only makes sense when considered in the context of a case.

Thus, there is no discussion around the search for a standard or intent of the legislature, because that "no artist can claim to reconstruct the intention of the legislature, without assuming that his own pre-understanding is, in turn, part of the interpretive process producing, with each new reading, a new direction." ${ }^{66}$ Ronald Dworkin makes valuable contributions to the topic discussed here. The author differentiates between the community that would be a mere accident, a community of rules and a community of principles ${ }^{67}$. If we are a community of principles, the law is not just a set of decisions (legislative and/or criminal) taken in the past so that such an understanding of the principles of law allows the system to "expand and contract organically (...),without the need for detailed legislation or court decisions for each of the possible points of conflict ${ }^{68}$.

This last reference is particularly important in Brazil, where it is believed that the problems of law are solvable by the constant alterations to the law or the establishment of new praetorian approach. Taking the example of Civil Procedure, it is clear that despite the incessant reforms through which law is passing and despite the "optimization" of the sys-

Cf. Hans-Georg Gadamer, Verdade e Método: traços fundamentais de uma hermenêutica filosófica, São Paulo, 1999, 459-460 and Ronald Dworkin, Uma Questão de Princípio, São Paulo, 2001, 220.

"The limits of my language denote the limits of my world. (...) The world is my world, because it proves the limits of language (language that only I understand) denote the limits of my world". $L$. Wittgenstein, Tractatus Logico-Philosophicus, São Paulo, 1968, 111 (\$5.6 and §5.62).

Hans-Georg Gadamer, note 63, p. 461.

Ana Maria Lopes, O Papel do Juiz na Hermenêutica Jurídica de Hans-Georg Gadamer. Revista da Faculdade de Direito da UFMG, Belo Horizonte, 36 (1999), 297. 
tem of precedents, the judicial crisis has not solved our problem because the problem is not in the text - as it might seem in a community of rules. The judicial activity in a community of principle is governed by the principle of integrity. That is, a legislator and a judge must act to build a coherent system of law. In the legislative's resulting decisions, the recipient must be recognized as its author ${ }^{69}$. Already evident in judicial decisions, is integrity shown in the position that judges should assume in the planning process: they should take it "as if" a "coherent set of principles" ${ }^{70}$ Are composed. The judge is expected to reach a valid decision that compensates for the indeterminacy of law supporting his decision making in the reconstruction of the legal system, so that he can be justified by an ordered series of principles.This task, which applies to the every judge (in any jurisdiction) means that he must decide a concrete case bearing in mind Law as a whole (through the principles), which is nothing more than his prior obligation under the constitution ${ }^{71}$. For this reason the principles should be rebuilt in the present, taking into account the past (so becoming reflective and not merely a repetition) and also the future, as an opening for future generations. The subservience to the past is a typical posture of "conventionalism," where law enforcement is performed automatically by the application of precedent (or, in our case, Overviews and/or prevailing jurisprudence) or subsumption of the law (and/or a Binding Precedent $)^{72}$. However, Dworkin also seeks to move away from what could be the opposite situation, i.e. legal pragmatism, where the judge acts instrumentally, aiming with his decision to consider would be best for the future ${ }^{73}$. Both lose the sense of the legal system as a whole: the first, conventionalism, is particularly important because of this trend - which is gaining momentum in Brazil - the use of precedent as a source of law ${ }^{74}$. Dworkin argues that the judge, in deciding a case, does not consider it as an isolated case, but as part of a whole (integrity) in a constructive process that the court continues ${ }^{75}$. This does not mean that the

Ronald Dworkin, note 10, p. 229.

Ronald Dworkin, note 10, p. 261.

Jürgen Habermas, note 7, p. 286.

72 Ronald Dworkin, note 10, p. 141.

73

We realize this position, for example, in cases involving the so-called "legalization of health," when the judge must decide whether or not the purchase of a remedy (or the performance of a medical procedure) at the expense of the state and its decision based on the proportionality principle takes account not necessarily of the case itself, but its possible future consequences. See below.

Rodolfo Mancuso, O precedente como fonte de direito, Caderno de Direito Processual Civil, 7 (2008), 03. This phenomenon is known as "mixed jurisdictions". Cf. Dierle Nunes, Alexandre Bahia, Por um novo paradigma processual. Revista da Faculdade Direito do Sul de Minas, 26 (2008), 79.

75 This knowledge of all principles, all the past seen in a network, is not an easy task. There appears the figure of Judge Hercules. Cf. Ronald Dworkin, note 10, p. 87. What we have here is a feature of argument, that is, Dworkin does not expect that all judges are like Hercules or worse, elect a court for that purpose. 
judge has to repeat the same decision as the last instance when faced with a similar case while the U.S. is historically a country of common law - because the judge, while implementing the law is also the author (because it adds something to the legal structure) and critic (who interprets the) past ${ }^{76}$. Law is therefore not taken as a given but as a construct ${ }^{77}$ and, as any given case is considered on its merits, can decree in a single correct conclusion. At the same time, because it is the correct answer for that case, the decision will not be taken as a standard which may automatically predetermine the outcome of other cases in future. Klaus Günther can also help us better understand how the process of judicial decision making works. Unlike Dworkin, Günther makes it clear that the process reconstruction of the legal system and of the case - both are not "data", as already shown by Dworkin but is rather performed by the parties in an adversarial process, under the eye of the magistrate who can thus maintain his impartiality. For Günther ${ }^{78}$ the decision must precede a process in which all relevant features of the case are taken into account. When the planning of this process is finished, it appears to the observer as a "rough sea" of competing standards trying to rule the situation and not a "one integral rule for a whole. Passive, harmonious and predetermined beforehand that would have regulated, absolutely, the application of its rules." ${ }^{79}$ If there are various valid standards that could govern a given case - prima facie rules - the discovery of which one is the appropriate standard is a task in which they participate, as stated, is by adversarial parties and the judge himself. To find out what the "prima facie" rules are - that is, what rules are valid in satisfying a criterion of universality, therefore, without consideration of the case - is a process that takes place through discourses of justification ${ }^{80}$. Once the standards are set (which prima facie is applicable), the process passes to what Günther calls for discourses of application, as we said, through the pursuit of the fullest possible description of the case and it's peculiarities ${ }^{81}$, you can see which of those standards (and no other) is the appropriate standard. Thus, there is no real conflict between the rules, but only the appearance of conflict. Abusive claims are evident when the regular enjoyment of a right implies a breach of the legitimate rights of others. There is no law, rule, precedent or case law that can provide all law enforcement situations, any rule (or similar) is applicable to a number of situations, but the reality is much richer/diverse and different situations that defy the law operators as they will cause conflict

Ronald Dworkin, Uma Questão de Princípio, São Paulo, 2001, 235-253.

A "roman en chaîne". Cf. Ronald Dworkin, note 68, p. 274 et seq.

Klaus Günther, Justification et application universalistes de la norme en droit et en morale, Archives de Philosophie du Droit, 37 (1992), 269.

Menelick de Carvalho Netto, Requisitos pragmáticos da interpretação jurídica sob o paradigma do Estado democrático de Direito, Revista de Direito Comparado, 3 (2000), 483.

Klaus Günther, Uma concepção normativa de coerência para uma teoria discursiva da argumentação jurídica, Cadernos de Filosofia Alemã, 6 (2000), 99. 
between those two provisions: the data of the case, "complementing" the standards, will provide subsidies to the decision.

Finally, Jürgen Habermas explains the tension between "facticity" and "validity" in the Jurisdiction: between legal certainty (positive law) and the attempt to generate correct decisions (legitimacy), a court must take into account the legal system (internal justification) as a repository of behavioral expectations that were stabilized, either by the legislature, or by the judiciary (or even by tradition and customs ${ }^{82}$ ).

At the same time, however, the decision calls for rational acceptability (external justification). To do this we must be attentive not only to the quality of the arguments but also to the very structure of argumentative procedure leading to the decision, to ensure the equal participation of those affected by the decision, without coercion (validity), despite the limitation of time (facticity) ${ }^{83}$. For a judicial decision to have certainty and rational acceptability, it must meet two conditions: internal reasons, i.e. to conceive of the law as a set of rules and principles, and rationale for external legitimacy that ensures the acceptability of the decision verified by observing that there is a procedure guaranteed equal participation in adversarial proceedings ${ }^{84}$. The very notion of what is "legal" is redefined as the parties to guarantee a "fair procedure" in which there is no guarantee of a particular outcome but rather the discursive clarification of the issues addressed so that the decision will have security that was not secured by "any" reasons, but only those that were relevant in the case $^{85}$. The emphasis on the particularities of the case, which reinforce the standards in the pursuit of an appropriate standard, does not transform the proceedings into one misleading argument, this is due to discursive practice in the search for the best argument opens up a double dimension to the sentence: the dimension of immanence, i.e. that the process represents a response to the event and a transcendent dimension: ${ }^{86}$

The procedure should be such that the prospects of the parties are specifically correlated with those that supported the discourse of justification, in order to verify the correspondence between the perspectives of participants in the judicial process and members of the legal community, represented by the impartial judge. Besides being a response to those persons, the right to claims raised by the parties, the sentence must be such that any people who were there in that case would receive the same decision. Gonçalves, Técnica processual e teoria do Processo, Rio de Janeiro, 1992, 115-125.

Cf. Jürgen Habermas, note 7, p. 291; Dierle Nunes, Alexandre Bahia, Eficiência processual: algumas questões, Revista de Processo, 169 (2009), 116. 


\section{Lack of awareness of mixing between legal systems: Brazil between civil law and common law.}

The problem becomes more serious due to the absence of perception of the mixture, the circulation of legal models or "bijuralism" (as it is known in Canada) between systems (or their misperception) that were typically civil law or common law. There are numerous studies in recent years ${ }^{87}$ which show this tendency to merge the traditions in the twentieth century: the experience of continental Europe became evident giving more space to the case law, and, conversely, a legislative orgy that offered legal forms to classical rules of common law ${ }^{88}$. And we Brazilians are averse to this phenomenon. Every day we witnessed the strengthening of the importance of the judgments of the courts, especially superior courts, on the grounds of judgments. However, this phenomenon of a "Brazilian common law" occurs without the worry of consolidation of a scientific "theory of precedent" for our country. This is because, in Brazil, the reference to the same processes and precedents as had been previously, give so little with the issues, debates and arguments which they originated. So, when one invokes a given precedent, it is autonomous in face of the underlying discussion - unlike what happens with the precedents of countries of stare decisis, as we shall see.

Customarily, in comparative law one theorizes on the question of how the superior courts make use of precedents ${ }^{89}$. This is nothing new in the practice of countries like the U.S. if there is (among other countries) that is the inspiration for our right to make a hybrid in which we value the above, we can also take away valuable lessons. The first question is that, even with precedent, the activity of ordinary judicial resolution of a case does not happen just by repeating previous cases. As shown by Edward Re, the precedent is a prin-

Antonio Gambaro, Common law e civil law: evoluzione e metodi di confronto. In: Federico Carpi, Due iceberg a confronto: le derive di common law e civil law, Milano 2009. Cf. Mirjan Damaška, The Common Law / Civil Law Divide: Residual Truth of a Misleading Distinction. In: Federico Carpi, The future of categories. International Association of Procedural Law, 2009, 1-13. Colin B. Picker, International Law's Mixed Heritage: A Common/Civil Law Jurisdiction, in: Federico Carpi, The future of categories. International Association of Procedural Law, 2009.

"[...] one can detect a trend towards codification in many Common Law countries. For instance Australia, England and the United States now have an extensive body of codes in the fields of bankruptcy, intellectual property, antitrust, banking regulation, securities and tax law. As to the United States of America, Judge Calabresi observed in 1982 that the United States have entered the "age of statutes" and that statutes may be used as sources of law beyond their terms.7 Others have even drawn the conclusion that the interpretation of statutes is America's new "primary source of law". Many American cases are indeed concerned with the interpretation of statutes, such as the Bankruptcy Act or the Internal Revenue Code and in carrying out this task, courts in the United States are basically using canons that have been developed by civilian methodology. Some states, such as California, even have complex civil codes. Katja Funken, "The Best of Both Worlds" - The Trend Towards Convergence of the Civil Law and the Common Law System. $<$ http://www.jurawelt.com/sunrise/media/mediafiles/13598/convergence.pdf>.

Simon Whittaker, note 48, p. 44. 
cipium, a starting point that will contribute to the decision. ${ }^{90}$ Not all precedents have the same "strength". Among them are the binding and the merely persuasive: what differentiates one from another is the practice of argument in court. Within a precedent we still distinguish between the part of reasoning of the precedent (principle) and the mere "dictum" (without binding power). It is perceived that a system based on stare decisis is not, however, stuck to reading "exegetical" precedent. The relationship is dynamic in building law and not static in terms of who takes as given the precedents of the past that should not be repeated.

Furthermore, there are two techniques that interest us in particular. One is the method of overcoming the preceding (overruling): the applicants may be nominated, with the Court that issued the previous (or may do so, ex officio), the abolition/reinterpretation of ancient precedent showing the change in the factual assumptions/entities who originated them. ${ }^{91}$ The other is the distinguishing, a way to escape the rigors of precedent: where it can be shown that the case has characteristics that differentiate it, that is, beyond the similarities, it is advocated that the Court should dismiss the case on grounds of new legal issues (or particular facts) not thought/discussed in the precedents. ${ }^{92}$ Both of these techniques can be fully used in Brazil as a way to circumvent the constitutional violations in the implementation of radical precedents (and the general impact of constitutional and federal issues). However, the problem becomes more serious in the implementation of cases previously tried, since there is not a discursive reconstruction of an event from the past for its application in the case being tried.

With Dworkin we learned that the courts, to judge a new case, should respect the institutional history of the application of that institute (thesis or case) as a "chain novel", but allowing properly justified disruption in line with its integrity. However, given the assumption that the Brazilian Ministers (and judges) must have decision-making freedom creates a framework of "interpretive anarchy" in which one cannot even respect the institutional history of the solution to a case within a court. Each judge from the court decides form an interpretative "ground zero", without respect for the integrity or the past analysis of that case, allowing the generation of as many understandings as are the judges.

As explained by Funken, the situation is different in other countries where civil law is commonplace: ${ }^{93}$

[...] most Civil Law courts - at least the ones in Europe - will, in practice, not easily overrule their former case law. This is due to the fact that they do not wish to undermine their authority by

Edward D. Re, Stare Decisis, Revista dos Tribunais, 702 (1994), p. 7; Also Ronald Dworkin, note 10, p. 274.

91

See as examples, blacks and the question of abortion in America. Cf. Alexandre Bahia, Recursos Extraordinários no STF e no STJ - Conflito entre Interesses Público e Privado, Curitiba, 2009, 56.

Cf. Dínio Garcia, Efeito vinculante dos julgados da Corte Suprema e dos Tribunais Superiores,

93 Revista dos Tribunais, 734 (1996), 40.

Katja Funken, note 88. 
correcting their own decisions. A comparative German-American study, for instance, found that, in the almost 50-year history of the German Federal Constitutional Court (Bundesverfassungsgericht), in which it published around 4000 decisions, it departed from precedents in fewer than a dozen cases. 31 This consistency is all the more remarkable in light of the fact that 78 different judges sat on the court during this period.

One cannot deny the trend of using a system similar to common law countries (of the use of "stare decisis" both from the horizontal point of view ${ }^{94}$ and the vertical ${ }^{95}$ ) also in civil law systems with respect to the binding force of precedents. Funken reports that in Europe: ${ }^{96}$

Spain and Germany, for example, enacted statutory provisions in recent decades that make some decisions of their constitutional courts expressly binding on courts and governmental institutions.33 In regard to Spain, Article 5.1 of the Organic Statute of the Judicial power states that "the Constitution is the supreme norm of the legal system and is binding for all judges and courts, who shall interpret and apply laws and administrative norms according to constitutional precedents and principles, in accordance with the interpretation of them resulting from the decisions handed down by the Constitutional Court."According to section 31(1) of the German Federal Constitutional Court Act (Bundesverfassungsgerichtsgesetz or BVerfGG), decisions of that court are binding "on the federal constitutional institutions, on the states and on all courts and agencies." While there is no comparable statutory provision fortifying the binding quality of the decisions of other highest courts of appeal in Germany, such as the Federal Supreme Court (Bundesgerichtshof) and the Federal Administrative Court (Verwaltungsgericht), there is a great practical uniformity due to the availability of appellate review and reversal. Concerning the situation in France, David and de Vries have stated that "...despite the absence of a formal doctrine of stare decisis there is a strong tendency on the part of the French courts like those of other countries, to follow precedents, especially those of higher courts [...] The attitude of lower courts towards the decisions of the Cour de Cassation is in substance quite similar to that of lower courts in common law jurisdictions towards decisions of superior courts." This should not come as a surprise, for one has to consider that in the highly bureaucratic court systems of France, Spain or Germany, a judge's career is negatively affected by too many reversals of his decisions. Due to that, judges will strive to do their best to deliver judgements consistent with the opinions of higher courts. On the European continent, this distinction is sometimes abbreviated by the phrase that precedents are binding de facto, not de iure. This quasi-normative effect of a higher court's decision is an intended means for achieving uniform and predictable application of the law. The authority of precedents is even greater when there is a settled line of cases. In Spain, Art 1.6 of the Codigo Civil even provides that a settled line of cases can be made binding by legislation.

However, the Brazilian way of implementing the aforementioned would be perceived as a very strange phenomenon by scholars of civil law in the countries of Europe and even the current outlook for the English system itself. As Whittaker states: ${ }^{97}$

94

95

96

97

A court is, in general, bound by its own decisions.

The decisions of higher courts are considered binding for lower courts.

Katja Funken, note 88.

In the original: "[...] Porque si las decisiones inglesas obligan, ello sucede solo en la medida en que un tribunal en el futuro así lo declare. Por tanto, el grado de autocontrol que podemos percibir que los jueces ingleses ejercen en el desarrollo del Derecho, puede ser explicado por su sentido de lo que es apropiado constitucionalmente, la factibilidad de construir normas adecuadas de suficiente aliento y fortaleza en el área de Derecho pertinente, la necesidad de certeza jurídica y la 
[...] Because if decisions require English, it occurs only to the extent that a court in the future so declaring. Therefore, the degree of self-control that we can see that the English judges have on the development of law, can be explained by their sense of what is constitutionally appropriate, the possibility of building adequate standards of sufficient vigor and strength in the area of law relevant to the need for legal certainty and urgency of justice in this case. So if we find that English judges sometimes accept radically new ways of thinking, in fact, new legal principles, we often refuse such an approach because we understand that this matter should be resolved by Parliament.

In Brazil, the use of the aforementioned "ground zero" is presented, even when overviews and past cases are presented, that is, the mere reference to "theories" of those not picked ensures greater integrity. And one of the uses of this phenomenon is more worrisome when the reasons for decisions based on principles (e.g. human dignity), general terms (e.g. the objective is good faith) and indeterminate concepts (e.g. well-founded fear of irreparable harm), in which each Judge promotes an integration of its anarchic content, even without regard to the contradictory. Of course, that this framework can be seen as exaggerated, but it tries to promote a warning and a challenge to researchers and "operators" in the general risk of a standardized operative without a consistent theory of how to articulate the precedents in our country.

\section{The Decisional Consequentialism}

One point that deserves to be revisited is the previously alluded to tendency of certain activists working in the field of the politicization of the judiciary and the legalization of politics, of the so-called 'decisional consequentialism' that would allow judges and courts to anticipate the impact of their decisions in the political, economic and social fields ${ }^{98}$, as judicial proceedings and procedural expertise required to enable the structuring of public policy. ${ }^{99}$ Obviously, a criticism of consequentialism cannot represent the defense of suppression of the legal procedure for accessing fundamental rights. Any talk of reducing access to justice (art. 5, inc. XXXV, CRFB/88) to seal the litigation (especially in the public interest) may represent the only means of impracticability for many in protecting their fundamental rights. Meanwhile, such a dilemma cannot prevent that we deal with the consequentialist view that the aforesaid part of several assumptions are not met: 1) the existence of an infrastructure and technical support, and of adequate discussion of the proce-

naturaleza apremiante de "justicia" en el caso concreto. Así, si bien a veces encontramos jueces ingleses que aceptan formas de razonamiento radicalmente nuevas, en verdad, nuevos princípios jurídicos, a menudo también descubrimos que rehúsan admitirlas con la digresión de que esta materia debiera ser resuelta por el Parlamento." Simon Whittaker, note 48, p. 45.

When it comes to Economic, Social and Cultural Rights it must be seen as to the peculiarity of their constitution in order to avoid what Canotilho perceives as a confusion between "social and political rights" and "public policy of social rights." When the courts try to make "real" social rights, promoting public policies, plunges in "normative nebulae ", as these rights, as opposed to individual rights, not always imply a corresponding provision by the state. See J. J. Canotilho, Estudos sobre Direitos Fundamentais, Coimbra, 2008, 97 et. seq. 
dural process in, allowing decisional subsidies, 2) the provision of resources and time of skilled persons to enable analysis in each case, of the impact of decision-making, and the more intangible assumptions 3) a consistent training of magistrates in the fields of sociology, economics, politics, administration and philosophy that allows a vision the case being tried, with the result of court decisions. ${ }^{100}$ Of course, these assumptions are utopian and even if they were met, would not shield the decision, and the legal system, from the presence of unexpected risks in a plural society. The technical reform of the judiciary, with changes, including the logic of the administration of justice (from a patrimonial administration to a managerial vision) can certainly contribute much more than a mere change of the codes, as it is in Brazilian law in the last twenty years. Better training of judges is important but none of this guarantees, by itself, more appropriate decisions.

Moreover, the very pluralism prevents us from defending a simplistic and sealed vision in the mode of implementation of public policies, since it by far transcends the field of court proceedings $^{101}$ - not to mention how targeted and limitedly such questions are presented.

\section{E. Public Interest Litigation in comparative law: brief considerations}

Another aspect to consider is the analysis of Public Interest Litigation (PIL) as it has been thematized in other countries. Its use is typically counter-majoritarian, or it has been provided to marginalized groups of the poor and vulnerable, as a space for the implementation of their rights in the procedura route.

In India, the PIL has fulfilled a central role in promoting the protection of civil liberties, labor rights, of gender justice, accountability of public institutions, environmental conservation and the guarantee of socio-economic rights, such as housing, health and education, among others. ${ }^{102}$ This has been relaxed, allowing the legitimacy to the so-called "epistolary jurisdiction". This phenomenon was marked by several decisions such as the case of "Sunil Batra v. Administration Delhi", begun by a letter that was written by an inmate in jail and presented to a judge of the Supreme Court. The prisoner complained of a brutal assault committed by the Head Warder against another prisoner. The Court treated this letter as a court order and, while there were several opposing views on the matter, ruled that: "...

100

For a similar sense, see Boaventura de Sousa Santos (et. al), Proposta de projectos para o Observatório da Justiça Brasileira, Coimbra, september 2009, p. 6.

101 As explained very well by Whittaker, in England "'...] En el ambiente moderno, esta es una frontera que a los jueces ingleses entusiasma observar (y ser vistos que la respetan) por diversos motivos: quieren prevenir que se les acuse de usurpar la función de un legislador democráticamente elegido; quieren evitar pronunciar sentencias que requieran la evaluación de elementos respecto de los cuales son inexpertos o están relativamente desinformados (en especial consideraciones de política social o económica); y quieren eludir tomar decisiones que, aunque puedan parecer generales en los términos en que son expresadas, arriesgan sembrar incertidumbre debido a su fragilidad en manos de tribunales posteriores. Simon Whittaker, note 48, p. 45.

K. G. Balakrishnan, note 4. 
Technicalities and legal niceties are no impediment to the court issuing a warning that the same or informal communication as a process of habeas corpus, if the basic facts are found. "103 (Free translation).

In South Africa we have many examples like that of the Campaign for Medicines for the treatment of the AIDS virus. As noted by Vinodh Jaichand: ${ }^{104}$

The Treatment Action Campaign made the government's attitude regarding the treatment of patients with the HIV virus a national issue. This mobilized NGOs who responded to the government's indifference toward those who suffer from AIDS, capitalizing on the State's inability to articulate a coherent position on the disease. Large numbers of concerned citizens took to the streets to show their impatience with the official attitude. People living with HIV were seen as victims of the government's inability to cope with the disease.

Consequently, when an official of the Treatment Action Campaign entered the country secretly carrying generic drugs against AIDS at a fraction of the usual selling price, threats of prosecution slowly receded in the face of what seemed to be the act of a courageous individual who decided to demonstrate the hypocrisy of the system. In an earlier action, the Treatment Action Campaign had opposed, in common with the government, the lawsuit filed by the Pharmaceutical Manufacturers Association, to block legislation in support of cheaper generic drugs. Under pressure, the union withdrew its lawsuit in court. One of the leaders of the campaign, who is also HIV positive, refused to take antiretroviral drugs until they were available to all public hospitals and clinics. The Treatment Action Campaign continued to question the inaction of the government, and now had the "public interest" that it sought.[...]

Regarding the aspect of "litigation", the Treatment Action Campaign brought together the best legal minds in addressing socio-economic rights - which in many countries may not be considered rights. The campaign had the support of several NGOs: Legal Resources Centre, Child Rights Centre, Community Law Centre, Institute for Democracy in South Africa and Cotlands Baby Sanctuary. The last three were amici curiae, or designated experts to clarify technical issues before the court, based on their expertise. After the Treatment Action Campaign had won in the Supreme Court, the government appealed to the Constitutional Court. This, in turn, decided in favor of the Treatment Action Campaign, stating that the government's program to prevent transmission from mother to child was inappropriate.

There are several possible examples. But we must start discussing PIL very seriously in our country, since in addition to its use against the marginalized majority, we cannot forget the use of a legalization in favour of political and economic hegemony groups, which already have access privileged political arenas and have consolidated their power in the judicial field. In these terms, we must also worry about the consolidation of a consistent study of the phenomenon and its reckless use in Brazil.

\section{F. $\quad$ Final Remarks}

In light of the considerations made we can state that:

01. We need to develop the theme of Brazilian institutional crisis otherwise we will have to continue to deal with the consequences (not causes) of systemic functional deficits, 
and it will not be possible to take fundamental rights seriously, and a policy of democratization of these rights.

02. We need to realize and establish a scientific basis for the Brazilian "mesh-up" (convergence) with the construction of a theory of precedents capable of understanding and criticizing the tendency of the courts, especially superior courts, to produce "ground zero" decisions, as if Law itself, tradition and history of the enforcement of legal principle under comment, in the concrete case, could be despised by the voluntarism (decisionism) of the judge;

03. Here again, we question the trend, inclusive of the area of procedural technique (see the technical overviews, special repetitive features or, of projections, incidence of the resolution of repetitive demands - arts. 895 to 906 of the PLS166 of 2010), the so-called "standardization of decisions" which will enable the courts to adjudicate theories and not cases, offering model decisions, without first discussing in a shared manner the formation of a decision-making paradigm that ultimately makes the lower courts and first grade judges nothing but repeaters of the automate model, transforming the judge's munus in mere generation of statistical data.

04. We need to question consequentialism and realize that, on the one hand, the judiciary cannot be required to replace the legislature or the administration in promoting public policies and, secondly, not to judge based on inferences about the possible consequences for the future of their current decisions.

05. Not that we, it is worth of notice, want to avoid a radical approach to the AngloSaxon model and completely reject the use of the technique of case law. This path today, in a mass justice such as ours, is in fact irreversible, and has undeniable virtues in terms of the economy and streamlining of procedures. What we cannot accept is a pure and simple standardization of judicial protection. If the statements of law cannot apply automatically and indisputably in all practical cases submitted to court, why does this happen with the jurisprudence set out by the higher courts? Is it the case that judges would have achieved the miracle that legislators admittedly proved powerless to accomplish? It is obvious that the mere literality of hypothetical and general rules, whether they are as the primary as the legislator's or derived such as the court's, will never be enough to give litigants a fair composition of conflicts promised by the Democratic State. As far as the task of summary trial is concerned, it is of utmost importance that any dispute finds just and appropriate remedy in court. Thus, the need for the sentence to be sensitive to what gives individuality to the cause is indisputable and pressing, and therefore will reflect in its grounds all data and arguments that litigants have brought to the process. Only then, the judicial pronouncement can respond, with propriety and fairness, the demand of those who await judicial protection, along with effective justice. It is not by means of a cold and sterile standardization of the decisions that this shall be accomplished. Much more important will be, in that direction, a well reasoned and rational sentence in light of the peculiarities of the case, in contradiction, even when it is stated to apply precedents of judicial precedents. 
06. And finally, we need to develop the theme of current use of the principles and general provisions without sufficient rational grounds, since their use enables a decision shielding due to the fact that the magical invocation of these would sufice, without being told the precise sense used, for the decision to be considered over and done. ${ }^{105}$ Techniques such as proportionality and principles such as human dignity, good faith, the supremacy of public interest, among others, cannot be seen as a modern way of saying "in the name of God."

In an institutional judicial framework and in which framework the ruling of the Judiciary encompasses all fundamental issues of law we need to understand that respect for the reasons for decisions should allow consistency with the institutional history and the contributions of the constitutionalized process.

105 Cf. A critical analysis in: Humberto Theodoro Júnior, Dierle Nunes, Uma dimensão que urge reconhecer ao contraditório no direito brasileiro: sua aplicação como garantia de influência, de não surpresa e de aproveitamento da atividade processual, Revista de Processo, 168 (2009), 128. 